Brit. J. industr. Med., 1964, 21, 110.

\title{
LUNG CANCER IN A FLUORSPAR MINING COMMUNITY II. Prevalence of Respiratory Symptoms and Disability
}

BY

\author{
W. D. PARSONS, A. J. de VILliERS, L. S. BARTLETT, and MARGARET R. BECKLAKE \\ From the Department of National Health and Welfare, Ottawa, and the Respiratory Division of the Joint \\ Cardio-Respiratory Service*, Royal Victoria Hospital, McGill University, Montreal, Quebec, Canada
}

(RECEIVED FOR PUBLICATION APRIL 23, 1963)

\begin{abstract}
A survey of respiratory symptoms, lung function tests, and chest radiography was carried out among the fluorspar miners of St. Lawrence, Newfoundland, in whom the incidence of carcinoma of the lung (De Villiers and Windish, 1964) had previously been shown to be 25 times greater than for the rest of the province.

The incidence of pneumoconiosis among the exposed population was low (1.93\%) and the incidence of 'chronic bronchitis' comparable to that reported for miners elsewhere, enabling one to dismiss these as a relevant factor in the high incidence of carcinoma.

The relevance of smoking is less easy to assess in these miners, among whom there are few nonsmokers and many heavy smokers. Extrapolation from the data of Doll and Hill (1956) suggests, however, that the prevalence of heavy smoking among the miners cannot be the sole factor responsible for the higher incidence of carcinoma compared with the rest of Newfoundland, but it might well be a contributory one. It appears therefore that the main factor causing the high incidence of carcinoma among these miners was the high level of radioactivity in the air and water in the mines (De Villiers and Windish, 1964).

The reduction in lung function tests appeared to be more closely related to the presence of bronchitis than to dust exposure, but the incidence of chronic bronchitis was apparently higher in men exposed for any length of time to dust risk than in men with insignificant exposure.
\end{abstract}

In their analysis of the mortality data for the town of St. Lawrence, Newfoundland, de Villiers and Windish (1964) found an incidence of carcinoma of the lung over 20 times greater than that in the rest of the province of Newfoundland. From 1956 to 1960,157 deaths due to this condition were reported for the rest of the province, giving a mortality rate of 0.092 deaths per 1,000 population, whereas in St. Lawrence the rate was 2.33 per 1,000 population (1956 census, males aged 20 and over, 454). An occupational factor associated with mining the ore of several fluorspar mines was suspected. An analysis of the ore mined did not reveal the presence of minerals previously associated with lung cancer, but high concentrations of radon daughters, suspected of being carcinogenic, were demonstrable in some areas of the two mines still operating.

Because of these findings, a health survey of the miners and ex-miners of St. Lawrence was carried out by the Department of National Health and

*Supported by a grant from the Medical Research Council of Canada.
Welfare, Ottawa. Interest was focussed on factors which might have a bearing on a high attack rate of carcinoma of the lung, to which the present miners were presumably also subject, particular attention being given to respiratory symptoms, disability, and smoking habits.

\section{Material, Procedure, and Methods}

The population studied included all the 280 men employed in any capacity in the two mines when the survey was undertaken in August, 1960. A further 94 men resident in the town of St. Lawrence entered the study on a voluntary basis. This group included many ex-mine employees who wished to avail themselves of the opportunity for a free medical examination because they were aware of the suspected high incidence of carcinoma of the lung in the employees of the two mines. Ten volunteer subjects from the neighbouring fishing town of Grand Bank were also studied, making a total of 384 men registered in the survey. Complete information was not obtained from 23 men (see defaulters, Table 1), and a further four men were not included because of inadequate records of the length and nature of their mining service, 
making a final total of 357. Except in the $60+$ year groups, which were small, it was not thought that the lapse rate could have significantly influenced the results obtained.

A questionnaire concerning all systems, and including questions on respiratory symptoms similar to those used by Higgins, Oldham, Cochrane and Gilson (1956) was completed by each man. At the time of the clinical examination, one of us (A.deV.) made certain that all the questions on respiratory symptoms had been answered. The questions analysed for the present survey were as follows:

1. Do you have a cough?

(Should only be answered 'Yes' if the cough occurs most days for at least three consecutive months each year even if attributed to smoking. Transient cough of shorter duration, e.g. with colds, should not be counted; they are dealt with later in the questionnaire. Clearing the throat does not count here.)

2. Do you usually bring up phlegm from your chest (not from the back of your nose)?

3. Are you troubled by shortness of breath? (If no: check: not even on hurrying on level or walking up a slight hill?)

4. Does your chest ever sound wheezy or whistling? (If no: check: not even when you have a cold?)

In the present study 'chronic bronchitis' was considered to be present if three positive answers were obtained to the four questions on respiratory symptoms noted above.

Smoking habits, recorded in detail on the questionnaire, were graded according to the amount of tobacco smoked daily, assuming one cigarette to be equivalent to $1 \mathrm{~g}$. tobacco, and $1 \mathrm{oz}$. pipe tobacco to be equivalent to 28 g. tobacco (Doll and Hill, 1950). Men who had smoked previously but stopped smoking for a year or more were classified as non-smokers.

The physiological tests done on each man were as follows:

1. Indirect maximal breathing capacity (Indirect M.B.C.), in $1 . / \mathrm{min}$. B.T.P.S., obtained from the F.E.V .0 .75 (Gandevia and Hugh-Jones, 1957) multiplied by 40 , by analysis of a tracing recorded on a Stead-Wells spirometer. (Tubing of $32 \mathrm{~mm}$. internal bore, and a mouthpiece of $30 \mathrm{~mm}$. bore and paper speed of $1,920 \mathrm{~mm} . / \mathrm{min}$.)

2. Maximal mid-expiratory flow (M.M.F.) in 1./sec. B.T.P.S., calculated from the same tracing in the manner described by Leuallen and Fowler (1955).

3. Peak flow rate (P.F.R.) measured on the Wright peak flow meter (1./min.) (Wright and McKerrow, 1959).

For these tests the reported results are the mean of three attempts except where one attempt differed by more than $25 \%$ from the other two, when the mean of these two was reported.

For comparison, the normal values for these three tests were predicted as follows: 1 . Indirect M.B.C. from age and height using the regressions of Goldman and Becklake (1959)*; 2. M.M.F. from age and height using

*A $15 \%$ reduction of the predicted value was made since the study was done at sea-level, whereas the data of Goldman and Becklake were collected at an altitude of approximately 6,000 ft. above seawere
level. the regression of Bates, Woolf, and Paul (1962); and 3. P.F.R. from age using the regression of Tinker (1961).

Chest radiographs $(14 \times 17$ in. $(35.5 \times 43 \mathrm{~cm}$. $))$ were taken for each man, and all plates were read by two experienced observers. $\dagger$

A clinical examination, urinalysis, E.C.G., and haemoglobin and haematocrit estimations were also performed for each subject but are not reported here.

The mining service of each man was computed to the nearest month from the payroll records of the mine, and an attempt was made to group the men according to dust exposure as follows:

Group 1.-Men with no mining service: included in this group were men who had been on the mine payroll in any capacity for less than 12 months.

Group 2.-Men with significant mining service (minimum over 60 months, mean 155.9 months) on nondusty jobs (i.e. all surface installations except the crusher house) and minimal exposure (less than 20 months, mean 2.3 months) in dusty jobs (i.e. in the crusher house or underground). If their exposure on dusty jobs was between 20 and 60 months, they were classified as group 4, i.e. mixed service.

Group 3.-Men with significant mining service (minimum over 60 months, mean 130.8 months) on dusty jobs (i.e. in the crusher house or underground), irrespective of what time they had spent in non-dusty jobs.

Group 4.-Men whose mining service did not qualify them for the above groups, either because it was mixed, i.e. involved work in dusty and non-dusty jobs, or because it was less than 60 months on either dusty or non-dusty jobs.

The composition of these four groups for age, together with the mean values for mining service and body surface area, are shown in Table 1.

\section{Results}

Prevalence of Radiological Changes.-Of the 258 men studied who had over 12 months' exposure in dusty occupations, i.e. miners, workers in the crusher house, and men with mixed service, five showed radiological changes of pneumoconiosis, a prevalence of $1.93 \%$. Another five were considered to have pre-silicotic changes, i.e. an increase in the lung markings.

A further 14 men were considered to have evidence of mild healed tuberculosis. All these men were miners, and 11 had had more than 60 months' service; the prevalence of healed radiological tuberculous disease among the miners was thus $3.9 \%$.

†Drs. A. R. Riddell and R. B. Sutherland, of the Pneumoconiosis Referee Board, Ontario, read the films using a classification based on that published in the Miner's Phthisis Medical Bureau: Report for the three years ended July 31, 1935: Union of South Africa. Cases read as 5 (generalized arborisation with partial mottling) and 6 (generalized small mottling) were considered to have pneumoconiosis and are so reported in this paper. 
TABLE 1

AGE, SURFACE AREA, RADIOLOGICAL FINDINGS AND SERVICE OF MINE EMPLOYEES OF DIFFERENT OCCUPATION GROUPS

\begin{tabular}{|c|c|c|c|c|}
\hline Dust Exposure & Group 1 & Group 2 & Group 3 & Group 4 \\
\hline Number & $56(4)$ & $43(3)$ & $183(9)$ & $75(7)$ \\
\hline $\begin{array}{c}\text { Age (yr.) } \\
20-29 \\
30-39 \\
40-49 \\
50-59 \\
60+ \\
\text { Mean age }\end{array}$ & $\begin{array}{c}32(4) \\
7 \\
4 \\
10 \\
3 \\
33 \cdot 5\end{array}$ & $\begin{array}{c}7(1) \\
8(1) \\
10 \\
13(1) \\
5 \\
45 \cdot 2\end{array}$ & $\begin{array}{l}27(2) \\
72(3) \\
56(1)^{*} \\
21(1)^{*} \\
79^{(2)} \\
3\end{array}$ & $\begin{array}{c}30(3) \\
15(3) \\
12 \\
9 \\
9(1) \\
38 \cdot 3\end{array}$ \\
\hline $\begin{array}{l}\text { Surface area }\left(\mathrm{m} .{ }^{2}\right) \\
\text { Mean } \\
\text { S.D. }\end{array}$ & $\begin{array}{l}1.818 \\
0.1424\end{array}$ & $\begin{array}{l}1.808 \\
0 \cdot 1843\end{array}$ & $\begin{array}{l}1.811 \\
0.1581\end{array}$ & $\begin{array}{l}1 \cdot 810 \\
0.1311\end{array}$ \\
\hline $\begin{array}{l}\text { Mean service (mth.) } \\
\text { 1. Non-dusty } \\
\text { 2. Dusty (i.e. underground or mill) }\end{array}$ & $\begin{array}{l}4 \cdot 4 \\
4 \cdot 4\end{array}$ & $\begin{array}{r}155.9 \\
2.3\end{array}$ & $\begin{array}{r}25.6 \\
130.8\end{array}$ & $\begin{array}{l}55 \cdot 9 \\
33 \cdot 1\end{array}$ \\
\hline
\end{tabular}

Numbers in brackets indicate defaulters.

* Four miners in the 40-49 year group and one in the 50-59 year group had pneumoconiosis (category 1); one miner in the latter group had carcinoma of the lung as did one man of $60+$ years in group 2 .

Two previously undiagnosed cases of carcinoma of the lung were revealed by the survey, the diagnosis being based on the radiological findings and confirmed by tissue examination subsequently. One of these was a miner aged 58 with 236 months of service; the other man, aged 62 years, had had 279 months' service on the surface.
Prevalence of 'Chronic Bronchitis'.-The prevalence of 'chronic bronchitis', using the definition above, in the various groups studied is shown in Table 2 , and was $4 \%, 16 \cdot 2 \%$, and $22 \cdot 1 \%$ respectively in the non-miners, the surface workers, and a combined group comprising miners, mill workers, and men with mixed service, i.e. the population at risk in

TABLE 2

PREVALENCE OF 'CHRONIC BRONCHITIS' IN THIS AND OTHER SURVEYED POPULATIONS

\begin{tabular}{|c|c|c|c|c|c|c|c|c|c|c|}
\hline \multirow{3}{*}{ Definition } & \multirow{3}{*}{ Reference } & \multicolumn{9}{|c|}{ Prevalence of 'Chronic Bronchitis' } \\
\hline & & \multicolumn{3}{|c|}{ Rural } & \multicolumn{3}{|c|}{ Urban or Industrial } & \multicolumn{3}{|c|}{ Mining } \\
\hline & & Area & Age & No. $(\%)$ & Area & Age & No. $(\%)$ & Area & Age & No. $\quad(\%$ \\
\hline $\begin{array}{l}\text { Three of the following } \\
\text { symptoms: cough, spu- } \\
\text { t u m, dy sp noea, } \\
\text { wheezing }\end{array}$ & Present study & $\begin{array}{l}\text { St. Lawrence } \\
\text { Group } 1\end{array}$ & $\underset{33 \cdot 5}{20-70}$ & $56 \quad(4 \cdot 0)$ & $\begin{array}{l}\text { St. Lawrence } \\
\text { s u r a c e } \\
\text { workers' } \\
\text { Group } 2\end{array}$ & $\begin{array}{c}20-70 \\
\text { mean } \\
45 \cdot 2\end{array}$ & $43 \quad(16 \cdot 2)$ & $\begin{array}{l}\text { St. Lawrence } \\
\text { miners with } \\
\text { dust exposure } \\
\text { G roups } 3 \\
\text { and } 4\end{array}$ & $\begin{array}{c}20-70 \\
\text { mean } \\
38 \cdot 8\end{array}$ & 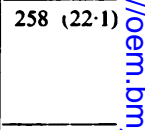 \\
\hline $\begin{array}{l}\text { Sputum for three } \\
\text { months in the year }\end{array}$ & $\begin{array}{l}\text { Fletcher, Elmes, } \\
\text { Fairbairn, and } \\
\text { Wood (1959) }\end{array}$ & & & & $\begin{array}{l}\text { London post- } \\
\text { men }\end{array}$ & $40-64$ & $(15 \cdot 7)$ & & & \\
\hline $\begin{array}{l}\text { Sputum for three } \\
\text { months and a chest } \\
\text { illness in the past three } \\
\text { years }\end{array}$ & $\begin{array}{l}\text { Higgins and Coch- } \\
\text { rane (1961) } \\
\text { Olsen and Gilson } \\
\text { (1960) } \\
\text { Carpenter, Cochrane, } \\
\text { Gilson, and Higgins } \\
\text { (1956) } \\
\text { Higgins (1957) } \\
\text { Higgins et al. (1959) } \\
\text { Higgins et al. (1956) }\end{array}$ & $\begin{array}{l}\text { R h o n d d a } \\
\text { Fach } \\
\text { Bornholm } \\
\text { Annandale } \\
\text { Vale of } \\
\text { Glamorgan }\end{array}$ & $\begin{array}{c}35-64 \\
55-64 \\
55-64 \\
25-65\end{array}$ & $\begin{aligned} 262 & (9 \cdot 2) \\
156 & (2 \cdot 6) \\
87 & (6 \cdot 9) \\
& \\
301 & (8 \cdot 6)\end{aligned}$ & $\begin{array}{l}\text { Staveley } \\
\text { Leigh }\end{array}$ & $\begin{array}{l}55-64 \\
55-64\end{array}$ & $\begin{array}{ll}81 & (14 \cdot 8) \\
84 & (10 \cdot 7)\end{array}$ & $\begin{array}{c}\text { Miners and } \\
\text { ex-miners } \\
\text { Miners and } \\
\text { ex-miners } \\
\end{array}$ & $\begin{array}{l}55-64 \\
55-64\end{array}$ & 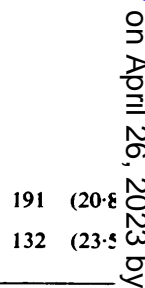 \\
\hline $\begin{array}{l}\text { Cough or sputum with } \\
\text { one other chest symp- } \\
\text { tom or wheezing and } \\
\text { weather effect }\end{array}$ & Rogan et al. (1961) & & & & & & & $\begin{array}{l}\text { Coalminers in } \\
\text { U.K. }\end{array}$ & & 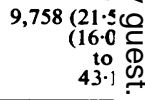 \\
\hline $\begin{array}{l}\text { Cough and wheezing } \\
\text { with reduced F.E.V.1.0 }\end{array}$ & Pemberton (1956) & Ayer, Mass. & $45-64$ & $238 \quad(11 \cdot 3)$ & Lynn, Mass. & $45-64$ & $131 \quad(12 \cdot 2)$ & $\begin{array}{c}\text { Pennsylvanian } \\
\text { coalminers }\end{array}$ & 45-64 & $242 \quad 33 \cdot 4 \frac{0}{0}$ \\
\hline $\begin{array}{l}\text { Cough and/or sputum } \\
\text { for three years or more }\end{array}$ & $\begin{array}{l}\text { Ferris and Anderson } \\
\text { (1962) }\end{array}$ & & & & $\underset{\text { Hampshire }}{\text { Berlin, }}$ & $25-74$ & $592 \quad(21 \cdot 2)$ & & 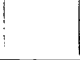 & \\
\hline
\end{tabular}


terms of dust exposure. The incidence of 'chronic bronchitis' among the population at risk in terms of exposure to underground conditions for 60 months or more, i.e. miners only, excluding mill workers, was $20.7 \%$.

Association of 'Chronic Bronchitis' and Respiratory Disability.-The association of chronic bronchitis with reduction in lung function tests is shown in Table 3 and Fig. 1 where the mean values for the subjects with 'chronic bronchitis' are compared with the mean values for the subjects of similar age who had no respiratory symptoms, i.e. gave negative answers to all four questions. As the groups were comparable in height, and since they were matched for age, the predicted values for each age group were similar and are plotted for comparison in Figure 1. The indirect M.B.C. and M.M.F. are significantly lower in 'chronic bronchitis' $(P<0.05$, using Student's $t$ test) in the two age ranges, 40-49 years and 50-59 years; in contrast, the P.F.R. values for the two groups were only significantly different in the latter

TABLE 3

VENTILATORY TESTS IN MEN WITH NO RESPIRATORY SYMPTOMS COMPARED WITH THOSE IN MEN WITH CHRONIC BRONCHITIS

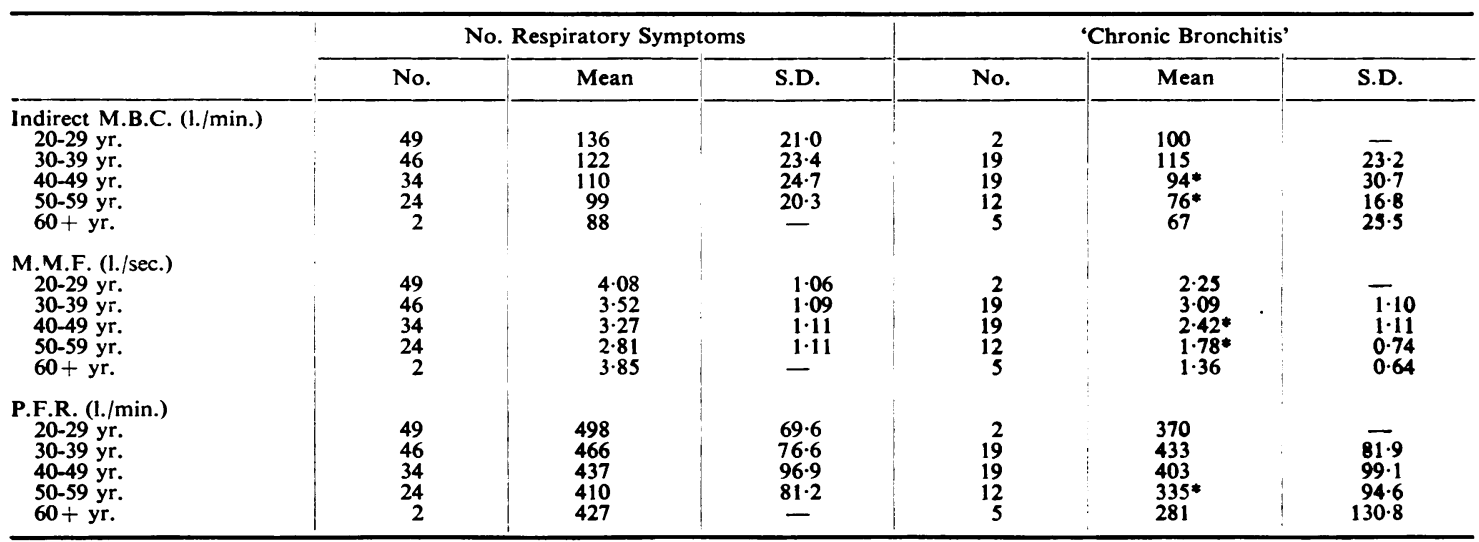

${ }^{*}$ Differs significantly from mean value in subjects with no respiratory symptoms $(P<0.05$ using Student's $t$ test).
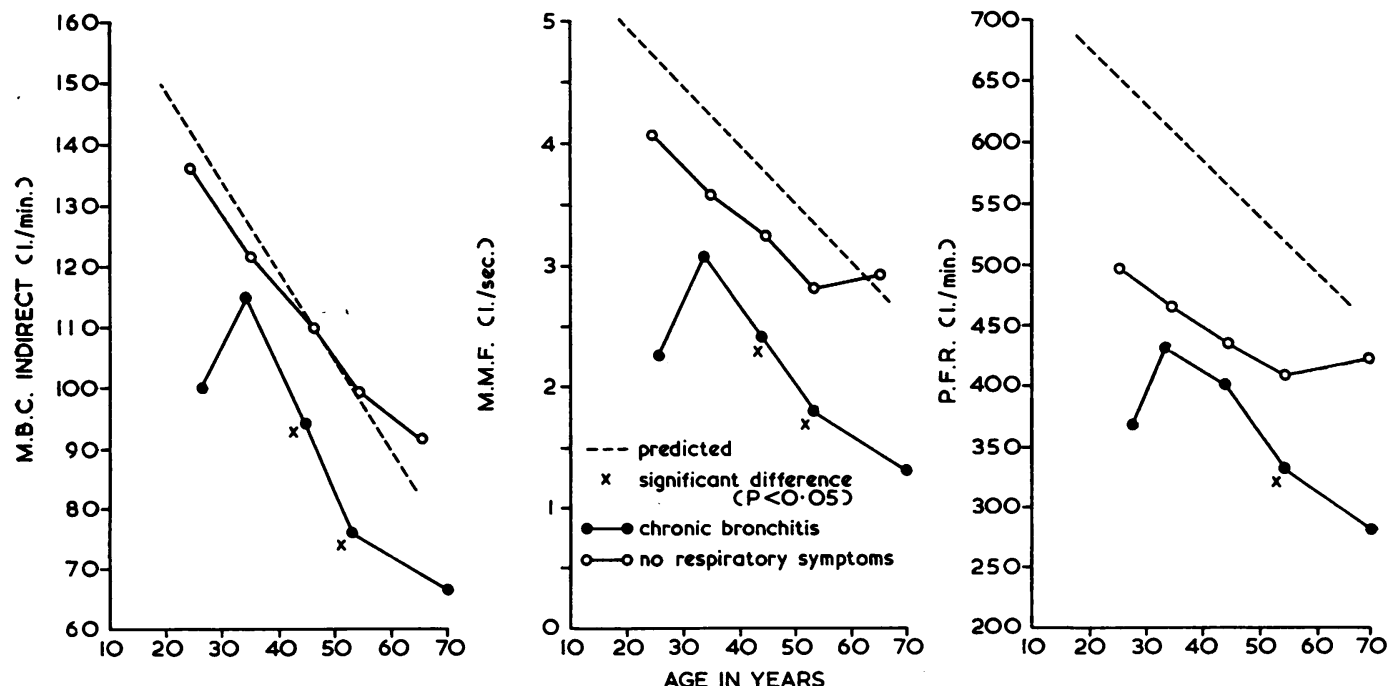

FIG. 1.-Lung function tests in relation to the presence of 'chronic bronchitis'. Indirect M.B.C. = indirect maximum breathing capacity calculated from F.E.V.0.75 $\times 40$ (1./min. B.T.P.S.); M.M.F. = maximal mid-expiratory flow rate (1./sec. B.T.P.S.) (Leuallen and Fowler, 1955); P.F.R. = peak flow rate (1./min.) (Wright and McKerrow, 1959). 
TABLE 4

VENTILATORY TESTS IN DIFFERENT OCCUPATION GROUPS

\begin{tabular}{|c|c|c|c|c|c|c|c|c|c|c|c|c|}
\hline & \multicolumn{3}{|c|}{$\begin{array}{c}\text { Group } 1 \\
\text { Non-miners }\end{array}$} & \multicolumn{3}{|c|}{$\begin{array}{c}\text { Group } 2 \\
\text { Surface Workers }\end{array}$} & \multicolumn{3}{|c|}{ Mroup 3} & \multicolumn{3}{|c|}{$\begin{array}{c}\text { Group } 4 \\
\text { Men with Mixed Service }\end{array}$} \\
\hline & No. & Mean & S.D. & No. & Mean & S.D. & No. & Mean & S.D. & No. & Mean & S.D. \\
\hline $\begin{array}{l}\text { Indirect M.B.C. (1./min.) } \\
20-29 \text { yr. } \\
30-39 \text { yr. } \\
40-49 \text { yr. } \\
50-59 \text { yr. } \\
60+\text { yr. }\end{array}$ & $\begin{array}{r}32 \\
7 \\
4 \\
10 \\
3\end{array}$ & $\begin{array}{r}138 \\
133 \\
117 \\
97 \\
107\end{array}$ & $\begin{array}{l}12.0 \\
28 \cdot 1 \\
18 \cdot 4 \\
15.3 \\
14 \cdot 5\end{array}$ & $\begin{array}{r}7 \\
8 \\
10 \\
13 \\
5\end{array}$ & $\begin{array}{r}137 \\
123 \\
112 \\
88 \\
77\end{array}$ & $\begin{array}{r}6.8 \\
13.2 \\
17.7 \\
16.0 \\
24.9\end{array}$ & $\begin{array}{r}27 \\
72 \\
56 \\
21 \\
7\end{array}$ & $\begin{array}{r}126 \\
122 \\
106 \\
98 \\
79\end{array}$ & $\begin{array}{l}29 \cdot 1 \\
27.9 \\
24.9 \\
44 \cdot 7 \\
18.5\end{array}$ & $\begin{array}{r}30 \\
15 \\
12 \\
9 \\
9\end{array}$ & $\begin{array}{r}141 \\
122 \\
103 \\
96 \\
70\end{array}$ & $\begin{array}{l}28 \cdot 1 \\
19 \cdot 3 \\
29 \cdot 1 \\
30 \cdot 5 \\
22 \cdot 1\end{array}$ \\
\hline $\begin{array}{l}\text { M.M.F. (1./sec.) } \\
20-29 \text { yr. } \\
30-39 \text { yr. } \\
40-49 \text { yr. } \\
50-59 \text { yr. } \\
60+\text { yr. }\end{array}$ & $\begin{array}{r}32 \\
7 \\
4 \\
10 \\
3\end{array}$ & $\begin{array}{l}4 \cdot 33 \\
4 \cdot 01 \\
3.85 \\
2 \cdot 60 \\
4 \cdot 00\end{array}$ & $\begin{array}{l}0.97 \\
1 \cdot 13 \\
0 \cdot 71 \\
0 \cdot 83 \\
1 \cdot 39\end{array}$ & $\begin{array}{r}7 \\
8 \\
10 \\
13 \\
5\end{array}$ & $\begin{array}{l}3.71 \\
3.49 \\
3.49 \\
2.51 \\
1.97\end{array}$ & $\begin{array}{l}1.49 \\
0.60 \\
0.75 \\
0.45 \\
1.62\end{array}$ & $\begin{array}{r}27 \\
72 \\
56 \\
21 \\
7\end{array}$ & $\begin{array}{l}3 \cdot 60 \\
3 \cdot 51 \\
2 \cdot 92 \\
2 \cdot 45 \\
2 \cdot 35\end{array}$ & $\begin{array}{l}1 \cdot 20 \\
1 \cdot 20 \\
1 \cdot 12 \\
0 \cdot 99 \\
1 \cdot 17\end{array}$ & $\begin{array}{r}30 \\
15 \\
12 \\
9 \\
9\end{array}$ & $\begin{array}{l}4 \cdot 34 \\
3 \cdot 36 \\
2 \cdot 47 \\
2 \cdot 96 \\
1 \cdot 87\end{array}$ & $\begin{array}{l}1 \cdot 21 \\
1 \cdot 07 \\
1 \cdot 08 \\
1 \cdot 52 \\
1 \cdot 17\end{array}$ \\
\hline $\begin{array}{l}\text { P.F.R. (1./sec.) } \\
20-29 \text { yr. } \\
30-39 \text { yr. } \\
40-49 \text { yr. } \\
50-59 \text { yr. } \\
60+\text { yr. }\end{array}$ & $\begin{array}{r}32 \\
7 \\
4 \\
10 \\
3\end{array}$ & $\begin{array}{l}493 \\
496 \\
425 \\
438 \\
459\end{array}$ & $\begin{array}{l}55 \cdot 3 \\
65.9 \\
48.0 \\
63 \cdot 6 \\
64 \cdot 4\end{array}$ & $\begin{array}{r}7 \\
8 \\
10 \\
13 \\
5\end{array}$ & $\begin{array}{l}504 \\
486 \\
459 \\
362 \\
349\end{array}$ & $\begin{array}{l}54.8 \\
51.0 \\
76.8 \\
83.1 \\
75.4\end{array}$ & $\begin{array}{r}27 \\
72 \\
56 \\
21 \\
7\end{array}$ & $\begin{array}{l}476 \\
452 \\
424 \\
408 \\
329\end{array}$ & $\begin{array}{r}101.9 \\
89.7 \\
103.9 \\
77.5 \\
116.1\end{array}$ & $\begin{array}{r}30 \\
15 \\
12 \\
9 \\
9\end{array}$ & $\begin{array}{l}504 \\
478 \\
430 \\
412 \\
313\end{array}$ & $\begin{array}{r}82.5 \\
52.5 \\
113.5 \\
112.6 \\
107.7\end{array}$ \\
\hline
\end{tabular}
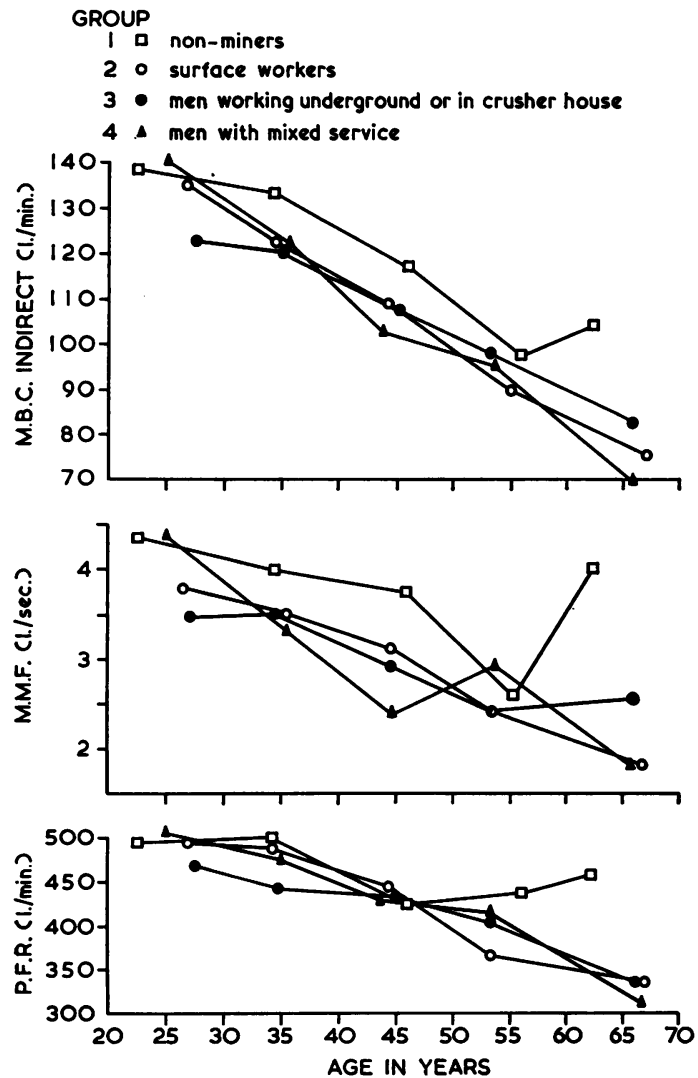

FIG. 2.-Lung function tests in relation to occupation: indirect M.B.C. = indirect maximum breathing capacity calculated from F.E.V.0.75 $\times 40$ (1./min. B.T.P.S.); M.M.F. = maximal midexpiratory flow rate (1./sec. B.T.P.S.) (Leuallen and Fowler, 1955); P.F.R. = peak flow rate (1./min.) (Wright and McKerrow, 1959); $x=$ differs significantly from mean values in other work groups (see text). age range. The small number of cases in the 20-29 years and $60+$ years groups makes a comparison of tests in these groups unsatisfactory.

Association of Occupation and Disability (Table 4 and Fig. 2).-The indirect M.B.C. and M.M.F. in non-miners (group 1) were in general higher than in all other groups though these differences were not significant at the $5 \%$ level. The only exception was in the 20-29 year group where these two tests were similar in groups 1,2 , and 4, whereas the men with appreciable dust exposure (i.e. miners and workers in the crusher house of group 3 ) had values significantly reduced.

P.F.R. values in contrast were similar in age groups up to 40 years. Surface workers in the 50-59 year span had significantly lower values than nonminers and miners, while the small numbers in the 60-69 year group made interpretation of the changes difficult.

Smoking Habits (see Table 5).-Though there were fewer non-smokers and more heavy smokers among miners and workers in the crusher house (group 3) compared to the other three work groups, these differences are not significant at the $5 \%$ level when tested for the difference between proportions (Arkin and Colton, 1956).

Similarly, when the smoking habits of the 153 men in all the work groups who had no chest symptoms were compared with those of the 57 men from all groups who were considered to have 'chronic bronchitis', there was no significant difference $(\mathbf{P}>$ 0.05 ) in the proportions of non-smokers and heavy smokers.

However, the general impression that the men in 
TABLE 5

SMOKING PATTERN IN THIS AND OTHER SURVEYED POPULATIONS

\begin{tabular}{|c|c|c|c|c|c|c|}
\hline \multirow[b]{2}{*}{ Population } & \multirow[b]{2}{*}{ No. } & \multirow[b]{2}{*}{ Age } & \multirow{2}{*}{$\begin{array}{l}\text { Prevalence of } \\
\text { 'Chronic } \\
\text { Bronchitis'* } \\
(\%)\end{array}$} & \multicolumn{3}{|c|}{ Tobacco Consumption (g./day) } \\
\hline & & & & $\underset{(\%)}{0}$ & $\begin{array}{l}1-14 \\
(\%)\end{array}$ & $\begin{array}{l}15+ \\
(\%)\end{array}$ \\
\hline $\begin{array}{l}\text { Non-miners } \\
\text { St. Lawrence (present study) } \\
\text { Rhondda Fach (Higgins, 1959) } \\
\text { Leigh (Higgins, 1959) } \\
\text { Vale of Glamorgan (Higgins, 1959) } \\
\text { Annadale (Higgins, 1959) }\end{array}$ & $\begin{array}{l}56 \\
50 \\
84 \\
86 \\
91\end{array}$ & $\begin{array}{l}20-70 \\
55-64 \\
55-64 \\
55-64 \\
55-64\end{array}$ & $\begin{array}{r}4 \cdot 0 \\
10 \cdot 7 \\
5 \cdot 8 \\
6.9\end{array}$ & $\begin{array}{l}21 \cdot 4 \\
24 \cdot 0 \\
19 \cdot 1 \\
25 \cdot 6 \\
20 \cdot 9\end{array}$ & $\begin{array}{l}14 \cdot 3 \\
42 \\
46 \cdot 4 \\
34 \cdot 9 \\
40 \cdot 7\end{array}$ & $\begin{array}{l}64 \cdot 3 \\
34 \cdot 0 \\
34 \cdot 5 \\
39 \cdot 5 \\
39 \cdot 5\end{array}$ \\
\hline $\begin{array}{l}\text { Miners } \\
\text { St. Lawrence (present study) } \\
\text { Rhondda Fach (Higgins, 1959) } \\
\text { Leigh (Higgins, 1959) }\end{array}$ & $\begin{array}{r}258 \\
94 \\
94 \\
47 \\
132\end{array}$ & $\begin{array}{l}20-70 \\
25-34 \\
55-64 \\
55-64 \\
55-64\end{array}$ & $\begin{array}{l}19 \cdot 2 \\
31 \cdot 9 \\
23 \cdot 5\end{array}$ & $\begin{array}{r}13 \cdot 7 \\
23 \cdot 4 \\
14 \cdot 9 \\
6 \cdot 5 \\
15 \cdot 9\end{array}$ & $\begin{array}{l}10 \cdot 9 \\
48 \cdot 9 \\
58 \cdot 5 \\
53 \cdot 1 \\
50 \cdot 8\end{array}$ & $\begin{array}{l}72 \cdot 1 \\
27 \cdot 7 \\
26 \cdot 6 \\
40 \cdot 4 \\
33 \cdot 2\end{array}$ \\
\hline
\end{tabular}

*See Table 2 and text for definitions.

St. Lawrence smoked heavily was confirmed by finding that the proportion of heavy smokers among the present group of miners and mill workers was considerably higher than in other studied groups of miners, e.g. coal miners and ex-miners in Leigh (Higgins et al., 1956) and Stavely (Higgins, Cochrane, Gilson, and Wood, 1959) both in England, and in Pennsylvanian coalminers (Pemberton, 1956). Smoking underground is not permitted in coal-mines, in contrast to the St. Lawrence fluorspar mines. The proportion of heavy smokers in group 1 (i.e. men with no mining service) was also high, however, and was significantly greater than in a group of city dwellers in Berlin, New Hampshire, studied by Anderson and Ferris (1962).

\section{Discussion}

The incidence of pneumoconiosis among the men currently employed in the St. Lawrence fluorspar mines who had had 12 months or more exposure to mine ore either in the mill or in the mine itself was only $1.93 \%$, a low figure compared, for instance, to the range of $9.1 \%$ to $41 \%$ reported by Rogan, Ashford, Chapman, Duffield, Fay, and Rae (1961) in the working population of eight collieries in different parts of the United Kingdom.

By contrast, the incidence of 'chronic bronchitis' among the St. Lawrence miners is comparable to what has been found among coal-miners in the United Kingdom, while the low incidence in the non-miners of the-St. Lawrence area is comparable to reported figures for rural populations elsewhere (Table 2). It must be borne in mind that the definition of 'chronic bronchitis' used in this study is not the same as that used in the United Kingdom. However, the criteria for the diagnosis in all instances are symptomatic, requiring usually the presence of three respiratory symptoms (Rogan et al., 1961) or, in the case of studies from the Pneumoconiosis Research Unit, two symptoms, namely sputum and a chest illness, the third symptom being the cough necessary to raise the sputum. The higher incidence among Pennsylvanian coal-miners is surprising since Pemberton's (1956) criteria included reduction in a lung function test and were therefore more rigid than the present criteria.

A significant deterioration in lung function appeared to be associated more closely with the presence of 'chronic bronchitis' (Fig. 1) than with exposure to dusty conditions in so far as this exposure is related to the various occupations listed. This is in keeping with observations elsewhere on miners (Higgins and Cochrane, 1961; Becklake, Zwi, and Lutz, 1959). The only exception was in the miners aged 20-29 years whose ventilatory tests were significantly lower than those of men in other occupation groups. Admittedly the ventilatory tests in non-miners were better for all age groups than for men employed in the mines in any capacity, but these differences were not statistically significant in any other group.

The possible relationship of any of the factors mentioned to the high incidence of carcinoma of the lung in St. Lawrence miners deserves consideration. The presence of pneumoconiosis in miners elsewhere does not appear to predispose to the development of carcinoma (Chatgidakis, 1960), and the low incidence in the St. Lawrence miners makes it reasonable to exclude this as a pertinent factor. It is less easy to assess the relevance of bronchitis. Its higher incidence among city dwellers has been attributed to atmospheric pollution (Fairbairn and Reid, 1958), a factor which has also been held responsible for the higher death rate from carcinoma of the lung among city dwellers (Stocks, 1959). However, the incidence 
of 'chronic bronchitis' among St. Lawrence miners is no higher than among other miners who are not prone to develop pulmonary carcinoma, and there is thus nothing to suggest that this condition has a bearing on the high carcinoma rate.

With regard to smoking habits, it is more difficult to draw definite conclusions. The most pertinent data in this respect would perhaps be a comparison of the smoking habits of the populations of St. Lawrence and of the rest of Newfoundland, either during the period 1956 to 1961 , when there were significant differences between the mortality rates for carcinoma of the lung in these populations, or in the immediately preceding years when the effects of smoking were presumably beginning to accumulate. Information on the smoking habits of the men of St. Lawrence at the time of the survey in 1960 does indicate a high proportion of heavy smokers, but there are no figures representing the smoking habits for the rest of Newfoundland for comparison. It is of interest however that Doll and Hill (1956) showed the incidence of deaths from carcinoma of the lung among heavy smokers (i.e. $25 \mathrm{~g}$. of tobacco daily) to be about 20 times greater than among non-smokers. From this, one might speculate that the more than 20 times greater incidence of carcinoma of the lung in St. Lawrence compared with the rest of Newfoundland might be considered attributable to smoking only if all the population of St. Lawrence smoked heavily ( $25 \mathrm{~g}$. or more of tobacco daily) while the population of the rest of Newfoundland were non-smokers. Since this is not the case, factors besides the heavy smoking habits of the St. Lawrence population must be operating to produce a high incidence of lung carcinoma. However, the significantly greater number of heavy smokers in this group of miners compared with miners elsewhere suggests that this factor may be important, either as a potentiating one or as a synergistic one with other carcinogens.

It is possible to draw certain conclusions about the relative value of the three lung function tests used in the survey. Both the indirect M.B.C. and the M.M.F. were successful in discriminating symptom-free subjects from men with 'chronic bronchitis' in the two age spans, 40-49 years and 50-59 years, whereas the P.F.R. only discriminated in the latter group (see Fig. 1). The greater discrimination value of tests which are dependent on the later phases of a forced expiration (i.e. indirect M.B.C. and M.M.F.) has also been pointed out by Fairbairn, Fletcher, Tinker, and Wood (1962) and is in keeping with the work of Fry and Hyatt (1960), who showed that, whereas maximum expiratory flow rates are developed in the early part of a maximal expiration when flow is effort-dependent, in the later phases the maximum flow rates are relatively independent of effort and therefore presumably are dependent on intrinsic bronchial anatomy. Thus while all three tests used are dependent on the size of the preceding inspiratory volume (i.e. are volume-dependent), the P.F.R. has the additional theoretical disadvantage of being a measurement made in that phase of expiration when flow is effort-dependent. On the other hand, the indirect M.B.C. calculated from the F.E.V.0.75 and the M.M.F. depends on an average of flow rates achieved by prolonging the observation time into the phase of expiration when flow rates are relatively independent of effort.

This study was carried out in the same circumstances as that of Drs. A. J. de Villiers and J. P. Windish (see this journal, p. 94). The present authors endorse their acknowledgements of assistance received.

\section{REFERENCES}

Anderson, D. O., and Ferris, B. G. (1962). New Engl. J. Med., 267,

Arkin, H., and Colton, R. R. (1956). Statistical Methods (College Outline Series No. 27). Barres and Noble, New York.

Bates, D. V., Woolf, C. R., and Paul, G. I. (1962). Med. Serv. J. Can., 18, 211 .

Becklake, M. R., Zwi, S., and Lutz, W. (1959). Brit. J. industr. Med., 16, 290.

Carpenter, R. G., Cochrane, A. L., Gilson, J. C., and Higgins, I. T. T. (1956). Ibid., 13, 166

Chatgidakis, C. B. (1960). In Proceedings of the Pneumoconiosis Conference, Johannesburg, 1959, ed. A. J. Orenstein. Churchill, London.

De Villiers, A. J., and Windish, J. P. (1964). Brit. J. industr. Med., 21, 94.

Doll, R., and Hill, A. B. (1950). Brit. med. J., 2, 739.

Fairbairn (1956). Ibid., 2, 1071. irn, A. S., Fletcher, C. M., Tinker, C. M., and Wood, C. H. (1962). Thorax, 17, 168.

- and Reid, D. D. (1958). Brit. J. prev. soc. Med., 12, 94.

Ferris, B. G., and Anderson, D. O. (1962). Amer. Rev. resp. Dis., 86, 165 .

Fletcher, C. M., Elmes, P. C., Fairbairn, A. S., and Wood, C. H. (1959). Brit. med. J., 2, 257.

Fry, D. L., and Hyatt, R. E. (1960). Amer. J. Med., 29, 672.

Fry, D. L., and Hyatt, R. E. (1960). Amer. J. Med., $29,672$.

Gandevia, B., and Hugh-Jones, P. (1957). Thorax, 12, 290. 79, 457. . (1957). Brit. med. J., 2, 1198.

Higgins, I. T. T. (1957). Brit.

, and Cochrane, A. L. (1961). Brit. J. industr. Med., 18, 93.

$\longrightarrow, \frac{}{\text { Oldham, P. D. C., Cochrane, A. L. }}$, (1959). Ibid., 16, 255 . Brit. med. J., 2, 904.

Leuallen, E. C., and Fowler, W. S. (1955). Amer. Rev. Tuberc., $72,783$.

Olsen, H. C., and Gilson, J. C. (1960). Brit. med. J., 1, 450.

Pemberton, J. (1956). Arch. industr. Hlth, 13, 529.

Rogan, J. M., Ashford, J. R., Chapman, P. J., Duffield, D. P., Fay, J. W. J., and Rae, S. (1961). Brit. med.J., 1, 1337.

Stocks, P. (1959). Ibid., 1, 74.

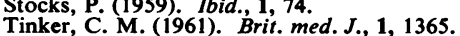

Winker, C. M. (1961). Brit. med. J., 1, 1365. 